\title{
Statistics Quantitative Solutions (SQS): As an Alternative Data Analysis Application for Students
}

\author{
Muh. Rusmayadi ${ }^{1}$, Malik Ibrahim $^{2}$, Aminullah $^{3}, \operatorname{Rody}_{\text {Satriawan }}{ }^{4}$, Sirajuddin $^{5}$ \\ ${ }^{1}$ Nahdlatul Wathan University of Mataram, Mathematic Department, \\ Jl. Kaktus No.1-3, Mataram, Mataram City, Indonesia \\ ${ }^{2}$ Nahdlatul Ulama University of Mataram, Mathematic Department \\ Jl. Pendidikan No.6, Selaparang, Mataram City, Indonesia \\ ${ }^{3}$ Mahasaraswati University of Mataram, Mathematics Department, \\ Jl. Amir Hamzah No.11, Sukun, Mataram City, Indonesia \\ ${ }^{4}$ Hamzanwadi University, Mathematic Department \\ Jl. Cut Nyak Dien No.85, Pancor, East Lombok, Indonesia \\ ${ }^{5}$ Muhammadiyah University of Mataram, Mathematic Department \\ Jl. KH. Ahmad Dahlan No.1, Pagesangan, Mataram City, Indonesia
}

\begin{abstract}
:
This study aims to develop simple communicative applications with high accuracy and easy to use by students, teachers, lecturers, or other researchers in the quantitative field. The menus presented have good interconnections, where input-output and data interpretation are carried out in one GUI. We use the Delphi GUI combined with Microsoft Office (Ms. Access, Ms. Excel, and Ms. Word), which is communicative, easy to use, easy distribution (spread), small memory, and portable and desktop-based. The development of this application uses a 4-D development model developed by Thiagarajan namely: Define, Design, Develop, and Disseminate. Based on the results of the development it was obtained the results of expert validation with a validity level of 4.33 which means "Very Good". Then in the limited trial obtained an average score of 4.28 which means "Very Good". While in the phase I and II field trials each of them obtained an average score of 4.21 and 4.22 which both mean "Very Good".
\end{abstract}

Keywords: GUI Delphi, Microsoft Office, SQS, 4-D Model

\section{Introduction}

The rapid development in the field of computer software, makes students spoiled with various software to calculate or process research data (Molugaram, 2017). Various types of software are offered such as SPSS, Minitab, SAS, Lisrel, Amos, Eviews, R-Software, Stata and so on. With the advantages and disadvantages of each software, it is a little unable to provide assistance to students to process their research data in order to obtain valid results. But in reality in the field, most students are not able to process their research data with various existing software (Hoffman, 2015).

The inability of students to use the software is caused by difficulties in using it and outputs that are not easily understood. To understand and be able to use the software, it takes a long training process. So that the alternative made by students in processing their research data is by using Microsoft Excel or manually. One effort taken to overcome this problem is to develop an application that is easy to use and the input-output is easy to understand. Rina Candra Noor Santi (2012) in Syaharuddin (2017) stated that Delphi is an easy-to-understand programming language, attractive in terms of interface, simple and light. In addition, the research conducted by Syaharuddin, et al (2017) on the development of the Delphi GUI as a learning media and database application development states that the Delphi GUI is very good in terms of interface, level of accuracy, and interconnection between the attributes used in all trials conducted. Departing from the explanation above, the research team was interested in developing the Delphi GUI to make an application for testing hypotheses on quantitative research that was easy to use, input-output and interpretation of the data explained in detail according to the students' needs in drawing their conclusions. 


\section{Method}

\subsection{Types of Research}

This research is a development research because in this study produce development products in the field of educational technology. Sugiyono (2016) says that development research is a research method used to produce certain products, and test the effectiveness of these products. So development research is a method for producing certain products or perfecting existing products and testing the effectiveness of these products. The products produced in this development research are in the form of hypothesis testing software on quantitative research based on Delphi. The software development model used is a 4-D model consisting of the Define, Design, Develop, and Dissemination stages developed by Thiagarajan, Semmel and Semmel which were modified according to the needs of the research team. The development model is in accordance with Figure 1 below.

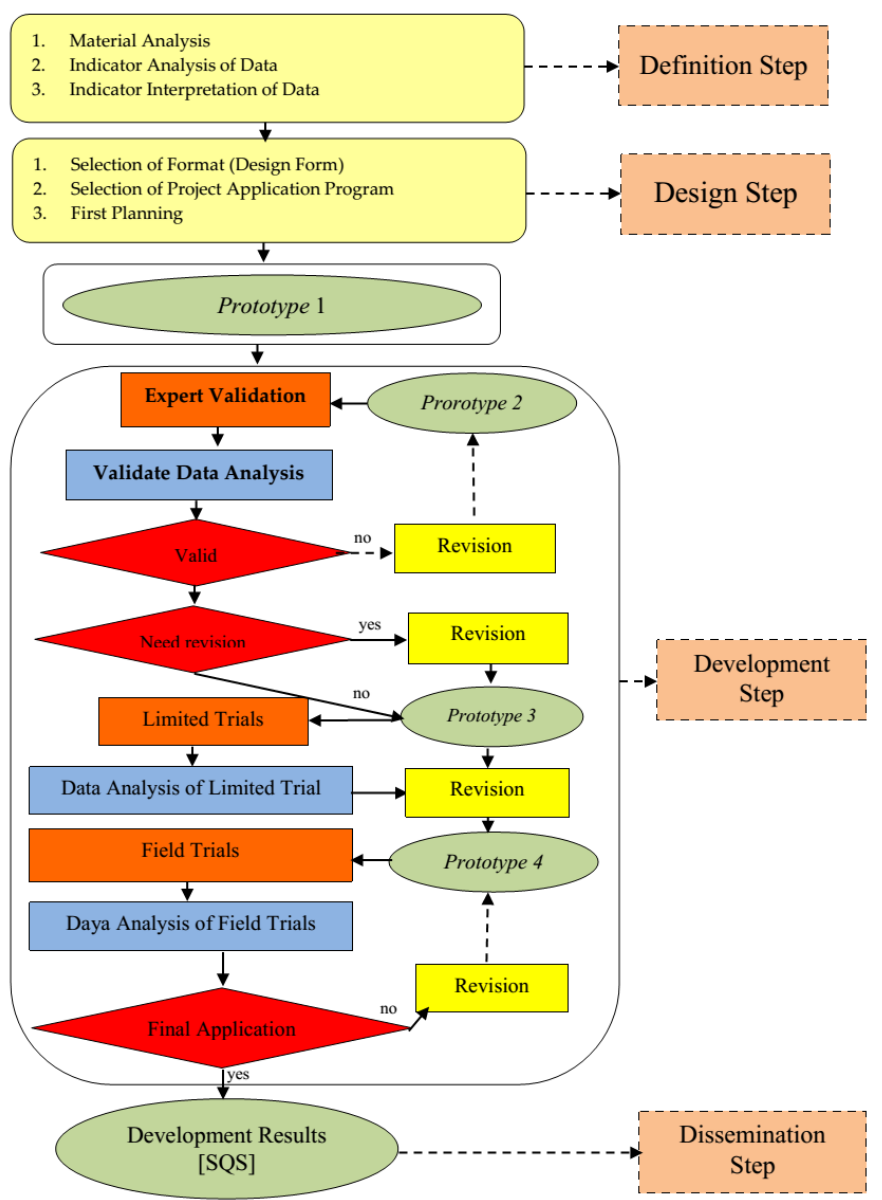

Figure 1: Modified 4-D Development Model

\subsection{Data Collection}

In accordance with the objectives of this development research, the data collected consisted of two types, namely (1) Qualitative, namely data in the form of input or advice from a team of experts and students during product testing both limited trials and field trials, and (2) Quantitative, namely data from the results of the questionnaire of expert and student teams during product testing both limited trials and field trials.

This study uses a data collection instrument in the form of a questionnaire regarding the feasibility of the Deplhi GUI for calculating hypothesis testing. This questionnaire is arranged based on the criteria contained in the application that has been made. The questionnaire in this study were: (a) expert team questionnaire, (b) limited trial questionnaire sheet, and (3) field trial questionnaire sheet.

\subsection{Methods of Analysis Data}

This study uses descriptive data analysis with one variable, namely the quality of application testing the null hypothesis based on research statistical material that has been contained in several references. The steps of data analysis are (a) Changing the assessment in qualitative form to quantitative using a Likert scale 5; (b) Calculating the average score for each validator; (c) Change the average score to a qualitative value with the following criteria in Table 1.

Table 1: Guidelines for Scoring

\begin{tabular}{|c|c|l|}
\hline No & Average Interval & \multicolumn{1}{|c|}{ Category } \\
\hline 1 & $\mathrm{R} \geq 4,20$ & Very good \\
\hline 2 & $3,40 \leq \mathrm{R}<4,20$ & Good \\
\hline 3 & $2,60 \leq \mathrm{R}<3,40$ & Pretty good \\
\hline 4 & $1,80 \leq \mathrm{R}<2,60$ & Not Good \\
\hline 5 & $\mathrm{R}<1,80$ & Very Poor \\
\hline
\end{tabular}

\section{Result and Discussion}

\subsection{Result of Validity and Respondents}

The results of each validated aspect obtained an average score from the material aspects, programming aspects, and design aspects of 4.33 which means "Very Good". Then the results of the respondents as many as 5 people at the limited trial stage obtained an average of 4.28 which means "Very Good". Then at the stage of the first stage of field testing as many as 11 respondents obtained an average of 4.21 which means "Very Good". While the results of phase II field trials as many as 18 respondents obtained an average of 4.22 which means "Very Good".

\subsection{Result of Product Trial}

\section{a. Validation Test Results}

The following is an explanation of the results of the validation test that has been carried out. 
1) In the material aspect, there is only one indicator included in the "Good Enough" category, namely the indicator of clarity of input, button and output intent. Besides these indicators are included in the "Good" category.

2) In the aspect of programming, each indicator gets a value that falls into the "Very Good" category. This shows that the product is developed very well from the aspect of programming.

3) In the design aspect, only one indicator is included in the "Very Good" category, namely the suitability indicator of size and type. In addition to the indicators included in the "Good" category. This shows that the product design developed is good. Even though the results are so, the researcher gets a "hint" on each process button is still incomplete.

b. Limited Trial Results

Based on the results of a limited trial questionnaire that has been conducted, out of 5 respondents, 3 respondents gave a "Good" assessment of the product developed and the rest gave a "Very Good" rating. Judging from the average score obtained at this stage, it shows that the product developed is very good for calculating hypothesis testing in quantitative research. Although the results as mentioned above, it was found several problems in the product such as there are buttons that have not been functioning and some forms have not been able to display the results perfectly.

c. Field Test Results in Stage I

At this stage, 7 of the 11 respondents gave a "Very Good" assessment of the product being developed and the rest gave a "Good" rating. The conclusion from the results of this phase I field trial is the same as the previous stage, which is to get the "Very Good" category. However, researchers get input, which is a process button icon that is less interesting and does not match the purpose and purpose of the icon.

\section{d. Field Test Results in Stage II}

At this stage, 10 of the 18 respondents gave a "Very Good" assessment of the product being developed and the rest gave a "Good" rating. So that the conclusions from the phase II field trials are the same as the previous stage, which is to get the "Very Good" category. However, there were some inputs from several respondents such as; background design and use of skins that are not good, application icons are not attractive and there are no minimize and maximize buttons.

\subsection{Final Product}

After making revisions as many as 3 (three) times, then the last product (prototype 4) which is named "SQS (Statistics Quantitative Solutions) is obtained. The final appearance is in accordance with Figure 2 below.

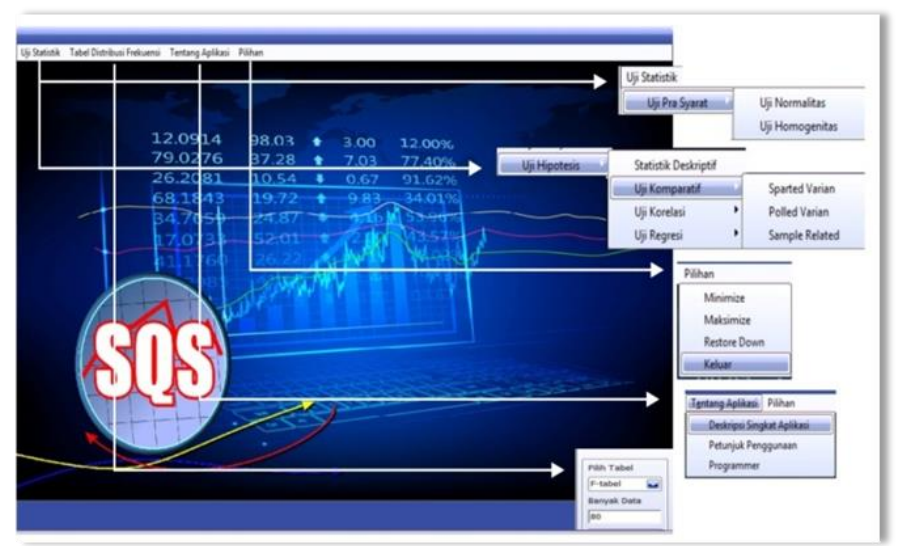

Figure 2: Display of SQS Main Menu

The details of the SQS application are in accordance with Table 2 below.

Tabel 2: Details Menu of SQS

\begin{tabular}{|c|c|}
\hline Menu & Sub Menu \\
\hline $\begin{array}{l}\text { Statistic } \\
\text { test }\end{array}$ & $\begin{array}{l}\text { 1.Pre-Terms Test consists of: } \\
\text { 1) Normality test } \\
\text { 2) Homogeneity Test } \\
\text { 2. Hypothesis testing, including: } \\
\text { a. Descriptive statistics } \\
\text { b. Comparative Test; Sparted } \\
\text { Variants, Polled Variants } \\
\text { and Sample Related } \\
\text { c. Correlation Test; Product } \\
\text { Moment, } \\
\text { Correlation and Partial } \\
\text { Correlation } \\
\text { d. Regression Test; Linear } \\
\text { Regression Test }\end{array}$ \\
\hline $\begin{array}{l}\text { Statistics } \\
\text { Table Test }\end{array}$ & Statistics Table Test \\
\hline $\begin{array}{l}\text { About the } \\
\text { Application }\end{array}$ & $\begin{array}{l}\text { 1. Application Description } \\
\text { 2. Instructions for Use } \\
\text { 3. About the Programmer }\end{array}$ \\
\hline $\begin{array}{l}\text { Display } \\
\text { Options }\end{array}$ & $\begin{array}{l}\text { 1. Minimize } \\
\text { 2. Maximize } \\
\text { 3. Restore Down } \\
\text { 4. Exit }\end{array}$ \\
\hline
\end{tabular}




\section{Conclusion}

Based on the results of data analysis and discussion in this study, it can be concluded that:

1) The end product is developed in the form of an application program which is then called "SQS" which is abbreviated as "Statistics Quantitative Solutions".

2) The final product developed in the form of a Graphical Use Interface (GUI) based application includes: (1) Normality Test, (2) Homogeneity Test, (3) Comparative Test (Sparted Variant, Polled Variant and Sample Related), (4) Correlation Test ( Product Moment, Double Correlation, and Partial Correlation), (5) Linear regression test, and (6) Statistical Test Table with lots of data (n) up to 1,000 .

3) At the expert validation stage there was a level of validity of 4.33 which means "Very Good". Then in the limited trial obtained an average score of 4.28 which means "Very Good". While in the phase I and II field trials each of them obtained an average score of 4.21 and 4.22 which both mean "Very Good".

\section{Acknowledgements}

The research team would like to thank the Indonesian Ministry of Research, Technology and Higher Education for providing funds for the success of this research. Respondents from various campuses, we also thank you. Finally to Institute for Research and Community Service of UNW of Mataram that has facilitated so that this activity is done well.

\section{References}

[1] Hoffman, J. I. E, "Hypothesis Testing: The Null Hypothesis, Significance, and Type I Error", Biostatistics for Medical and Biomedical Practitioners Journal, pp. 153-158, 2015

[2] Molugaram, K dan Rao, G. S. "Hypothesis Testing. Statistical Techniques for Transportation Engineering Journal, pp. 339382, 2017

[3] Ross, S. M, "Testing Statistical Hypothesis", Introductory Statistics Journal, VII (4), pp. 381432, 2017

[4] S. Thiagarajan, D. S. Semmel dan M. I. Semmel, Instructional Development for Training Teachers of Exceptional Children: A Sourcebook. National Center for Improvement of Educational Systems DHEW/OE. Washington, D.C, 1974
[5] Syaharuddin, et al, "JYSIM: Desktop Application to Increase Lecturer Publication Ratio", International Journal of Innovative Science, Engineering \& Technology, IV (11), pp. 197-201, 2017.

[6] Syaharuddin, Delphi for Education: Matematika, Multimedia, \& Database, Jawa Timur: Wade Group, 2018

[7] Trafimow, D dan Brian, D. E., "Null Hypothesis Signifikance Testing and Type I Error: The Domain Problem", New Ideas in Psychology Journal. 45 (1), pp. 19-27, 2017

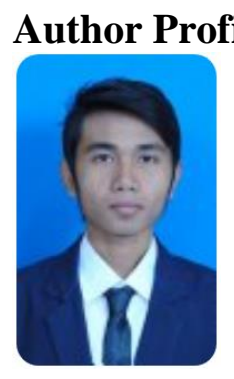

Muh. Rusmayadi, A Lecturer at the Mathematics Department of the Nahdlatul Ulama University of Mataram, graduated from the Surabaya Institute of Technology with a concentration in Statistics. Now as Chair of the Mathematics Education Study Program. Actively doing research in the field of Mathematics Education. 